\title{
Surface Water Pollution around Dhaka Export Processing Zone and Its Impacts on Surrounding Aquatic Environment
}

\author{
M. S. Islam ${ }^{* 1,2}$, A. Sultana ${ }^{1,2}$, M. S. Sultana ${ }^{2}$, M. Shammi ${ }^{2}$, M. K. Uddin ${ }^{2}$ \\ ${ }^{1}$ Department of Environmental Biology and Chemistry, Graduate School of Science and \\ Engineering for Research 1University of Toyama, Gofuku 3190, Toyama 930-8555, Japan \\ ${ }^{2}$ Department of Environmental Sciences, Jahangirnagar University, Dhaka-1342, Bangladesh
}

Received 21 May 2016, accepted in final revised form 3 July 2016

\begin{abstract}
This study based on the physicochemical parameters was conducted to determine the pollution status in the aquatic environment of Dhaka Export Processing Zone (DEPZ) area. A total of 5 water samples were collected on the basis of their distance from the effluent outlet and were examined. Physicochemical parameters like color, temperature, $\mathrm{pH}$, electric conductivity (EC), total dissolved solid (TDS), total suspended solid (TSS), total hardness, total alkalinity, dissolved oxygen (DO), biochemical oxygen demand (BOD) and chemical oxygen demand (COD) were measured via standard determination method. Physicochemical analyses revealed that most of the water quality parameters exceeded the recommended levels set by the Department of Environment (DoE), Bangladesh. The concentrations were found decreasing with increasing distance from the effluent outlet. A very strong positive correlation was found between BOD and COD in all sampling points. Both BOD and COD values had a strong negative correlation with dissolved oxygen (DO). The results indicated that the surrounding aquatic environment is exceedingly contaminated by various pollutants released from DEPZ which is highly vulnerable for the species on that ecosystem.
\end{abstract}

Keywords: Industrial effluents; Surface water quality; DEPZ Industrial area; Water pollution; ETP.

(C) 2016 JSR Publications. ISSN: 2070-0237 (Print); 2070-0245 (Online). All rights reserved. doi: http://dx.doi.org/10.3329/jsr.v8i3.27819 J. Sci. Res. 8 (3), 413-425 (2016)

\section{Introduction}

The surface water quality of a region is determined by the local topography, hydrology and hydrogeology in the catchment area, along with climatic factors and anthropogenic influences [1,2]. Surface water has the highest susceptibility to pollution because of waste and wastewater accessibility [3]. In most of the cases, the rivers are the main choices to hold and bear the responsibility of pollutants, especially in the developing countries [4]. In

\footnotetext{
* Corresponding author: sisumon2009@gmail.com
} 
recent years, the river systems in Bangladesh have become more polluted as a consequence of rapid population growth, uncontrolled development on the riverbanks, urbanization, unplanned industrialization and agricultural operations [5]. Industries are prime polluters because they utilize a huge amount of water and release untreated wastewater throughout the production cycle of a product. Newly booming processing industries such as tanneries, steel plants, battery producers, engineering and textiles also contribute to this problem [5]. The careless disposal of untreated wastewater and solid waste to the water system significantly contributes to the poor quality of the water. The polluted water becomes a threat to public health, livestock, wildlife, fish and other biodiversity. These pollutants have potential to retard the growth and aquatic flora and fauna [6].

The Dhaka Export Processing Zone (DEPZ) being the 2nd EPZ and the largest industrial belt of Bangladesh has started its operation in 1993 and at present houses 92 industrial units which are categorically the leading pollution creators. The list of different industries along with their unit number is given in Table $1[7,8]$. Every industrial unit is compelled to have their own effluent treatment plant (ETP) to treat their wastewater. However, so far only a few industries are following the rules regarding ETP. It was found that most of the industries with ETP facilities hardly ever operate their ETP to save production costs. As a result, most of these industries discharge untreated or poorly treated industrial wastewater, effluent and even sludge into the surrounding environment which increases the concentrations of pollutant, resulting in adverse effects on macrophytes, soil fauna and human health [9-12]. The wetlands and some of the streams located around the DEPZ area have already been affected from water pollutants discharged from DEPZ [4]. Therefore, it is an urgent need to figure out the present status of industrial pollution, redress environmental problems and adopt future mitigation strategy.

Table 1. Types and number of industrial units in DEPZ.

\begin{tabular}{lll}
\hline No & Type of Industries & Number of units \\
\hline 1 & Cap/Accessories/Garments & 42 \\
2 & Textile/Knitting & 22 \\
3 & Miscellaneous & 11 \\
4 & Plastic goods & 6 \\
5 & Footwear/Leather goods & 4 \\
6 & Metal products & 2 \\
7 & Electronic goods & 2 \\
8 & Paper products & 1 \\
9 & Chemical and fertilize & 1 \\
\hline
\end{tabular}

This study is an attempt to systematically examine the physicochemical parameters of the DEPZ adjacent water bodies. The results will be compared with the standards set by Department of Environment, Bangladesh to measure the extent of pollution load. This research work will reveal the present pollution status around DEPZ area which will be a basis of future research and monitoring activities for preventing water pollution around 
this area. The approach will also help to adopt an effective effluent management strategy towards control over enhanced pollution level.

\section{Materials and Methods}

\subsection{Study area}

DEPZ contiguous Dhalai Beel was selected as the study area in the present research work which is located at about $35 \mathrm{~km}$ south-east of Dhaka, the capital city of Bangladesh. This area belongs to Dhamsona Union under Savar Upazila of Dhaka District. There are two export processing zones (old and new) are in service within this belt divided by the national highway. The area comprises of irregular elevated topography on which people live and surrounding low lying areas are mostly used as cultivation land and water bodies. The adjacent area of the DEPZ effluent outlet became an unexpected waste dumping ground receiving the wastewater and its perimeter growing larger by excess precipitation and run off.

\subsection{Sample collection and preservation}

A total of 5 wastewater samples (each containing $1000 \mathrm{~mL}$ ) were collected from the effluent outlets and 4 other locations during dry season. The sampling starting from the point source and the distance from one sampling point to another was approximately 100 meters. The locations of the sampling points were given in Fig. 1 and Table 2. The samples are denoted as $S_{1}, S_{2}, S_{3}, S_{4}$, and $S_{5}$ respectively with their sampling points. The sampling was done very carefully using spot sampling techniques. The water samples were collected in sterilized containers with caps as per APHA method [13]. They were thoroughly cleaned by rinsing with $20 \% \mathrm{v} / \mathrm{v} \mathrm{HNO}_{3}$ and deionized water followed by repeated washing with sample water to avoid contamination in the bottle. The sampling containers were marked by a permanent marker pen for remarking the sample number. The water samples were filtered using Millipore membrane filters (Omnipore TM, Ireland) composed of mixed cellulose with $0.45 \mu \mathrm{m}$ pores and then stored in polystyrene bottles and kept at $4^{\circ} \mathrm{C}$.

\subsection{General water quality analyses}

The study was intended to measure wastewater color, temperature, $\mathrm{pH}, \mathrm{DO}, \mathrm{EC}$, total hardness, TDS, TSS, alkalinity, BOD and COD. The wastewater color was evaluated visually. The odors of the collected water samples were smelled and noted. Other physicochemical parameters such as $\mathrm{pH}, \mathrm{EC}, \mathrm{DO}$ and temperature of the samples were measured on the spot using glass electrode $\mathrm{pH}$ meter (pHep, HANNA), EC meter (HI 8033, HANNA), DO meter (H19143, HANNA) and thermometer respectively. TSS and TDS were measured by gravimetric method [13]. Total hardness indicates the 
concentration of calcium and magnesium ions only [14] was measured by a complexometric titration by using EDTA [13]. Alkalinity was determined by titration method with standard acid using changes in the color indicator (phenolphthalein/ methyl orange) at room temperature [13]. COD was measured via a Closed Reflux, Titrimetric Method [13] and BOD of the collected effluent samples was measured [13] using a HANNA Auto Cal. DO meter (HI 9143 microprocessor). In order to ensure analytical quality, three replicates of each sample were prepared and analyzed simultaneously.

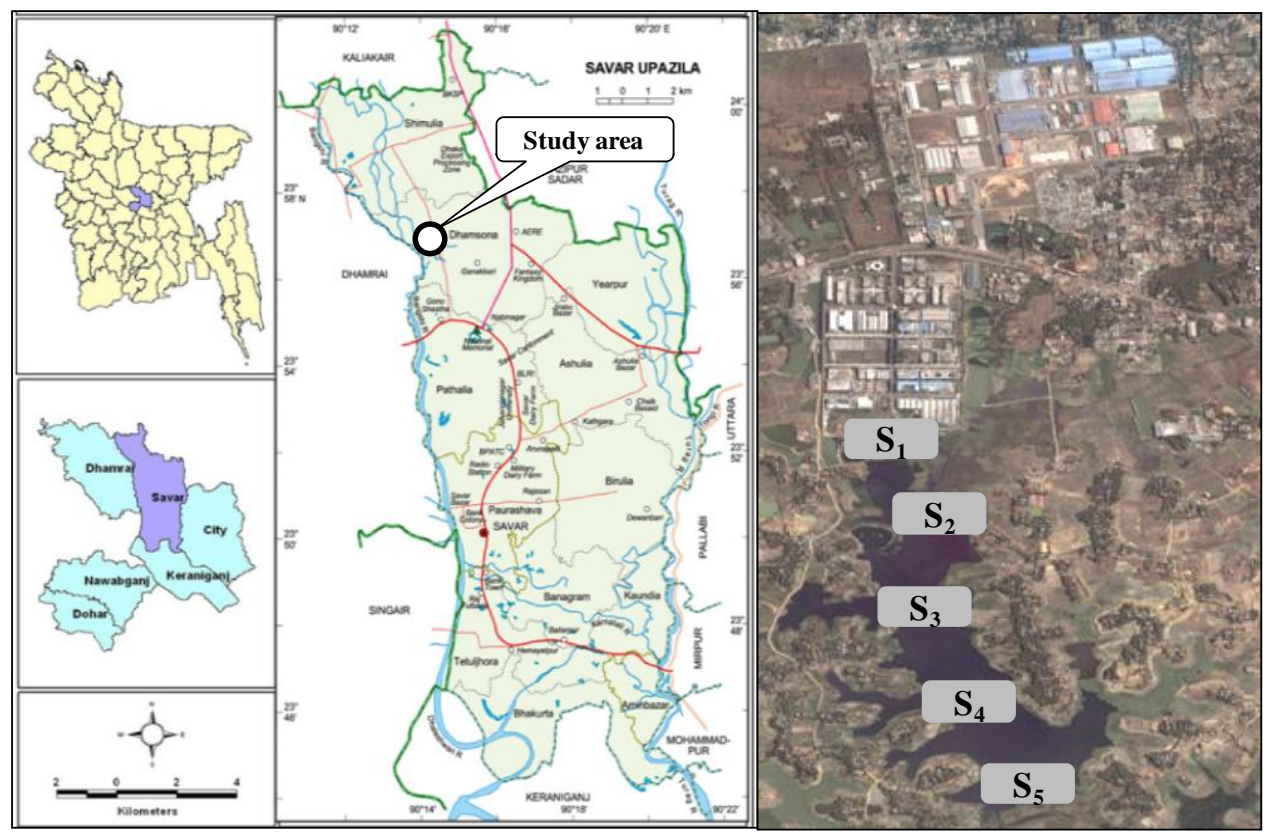

Fig. 1. Location of the study area and sampling points.

Table 2. Locations of sampling sites and sample code.

\begin{tabular}{llll}
\hline Sampling points & Sample code & $\begin{array}{l}\text { Distance from the } \\
\text { point source }(\mathrm{m})\end{array}$ & Location \\
\hline 1 & $\mathrm{~S}_{1}$ & 0 & $23^{\circ} 95^{\prime} 81^{\prime \prime N}$ and $90^{\circ} 26^{\prime} 43^{\prime \prime} \mathrm{E}$ \\
2 & $\mathrm{~S}_{2}$ & 100 & $23^{\circ} 95^{\prime} 54 " \mathrm{~N}$ and $90^{\circ} 26^{\prime} 39^{\prime \prime} \mathrm{E}$ \\
3 & $\mathrm{~S}_{3}$ & 200 & $23^{\circ} 95^{\prime} 42^{\prime \prime} \mathrm{N}$ and $90^{\circ} 26^{\prime} 33^{\prime \prime} \mathrm{E}$ \\
4 & $\mathrm{~S}_{4}$ & 300 & $23^{\circ} 95^{\prime} 25^{\prime \prime} \mathrm{N}$ and $90^{\circ} 26^{\prime} 24^{\prime \prime} \mathrm{E}$ \\
5 & $\mathrm{~S}_{5}$ & 400 & $23^{\circ} 94^{\prime} 88^{\prime \prime} \mathrm{N}$ and $90^{\circ} 26^{\prime} 32^{\prime \prime} \mathrm{E}$ \\
\hline
\end{tabular}

\subsection{Statistical analysis}

The changing trends of physicochemical parameters were calculated along with the variable distance from the effluent outlet. To analyze the trends of change in contamination loads, a Microsoft Excel spreadsheet was applied. Pearson's correlation 
coefficient matrix was also calculated for all physicochemical parameters to trace the correlation among the parameters. The significance level in this study was $p<0.05$.

\section{Results and Discussion}

\subsection{Physicochemical parameters}

The average concentrations of physicochemical parameters in 5 different sampling locations are given in Table 3. The water quality of these sampling points revealed a high level of water pollution when compared with the DoE, Bangladesh recommended values [15].

Table 3. The average concentration of physicochemical parameters of the wastewater.

\begin{tabular}{llll}
\hline Parameters & DoE standard & Mean & Range \\
\hline Temperature $\left({ }^{\circ} \mathrm{C}\right)$ & $40-45$ & 33.8 & $32-36.5$ \\
pH & $6.5-9.2$ & 9.41 & $7.59-11.45$ \\
EC $\left(\mu \mathrm{S} \mathrm{cm}^{-1}\right)$ & 1200 & 2614 & $1850-3650$ \\
Total Hardness $\left(\mathrm{mg} \mathrm{L}^{-1}\right)$ & 330 & 202.4 & $180-220$ \\
TSS $\left(\mathrm{mg} \mathrm{L}^{-1}\right)$ & 150 & 259.4 & $180-316$ \\
TDS $\left(\mathrm{mg} \mathrm{L}^{-1}\right)$ & 2100 & 1817.8 & $895-2559$ \\
Total Alkalinity $\left(\mathrm{mg} \mathrm{L}^{-1}\right)$ & 500 & 147 & $137-155$ \\
DO $\left(\mathrm{mg} \mathrm{L}^{-1}\right)$ & $4.5-8.0$ & 1.50 & $0.89-2.3$ \\
BOD $\left(\mathrm{mg} \mathrm{L}^{-1}\right)$ & 50 & 315 & $89-583$ \\
COD $\left(\mathrm{mg} \mathrm{L}^{-1}\right)$ & 200 & 538.6 & $283-820$ \\
\hline
\end{tabular}

\subsubsection{Color and temperature}

Highly colored liquid effluents with pungent odor were observed in the effluents of the study area as textile and dyeing industries are using various kinds of dyes for coloring their products and it becomes lighter with the increasing distance. This colored water released into the environment causing severe ecological damage as they prevent sunlight to reach the water, an essential element for photosynthesis for the primary producers [16]. As a result, oxygen depleting environment was created.

In textile and dyeing industries, hot water is released from scouring and boiler section and the hot water was discharged into Dhalai Beel, which results the temperature increment. These hot water losses temperature to considerable extent as it mixes with other effluents in the main drain. In the present study the effluent receiving water temperature ranged from 32 to $36.5^{\circ} \mathrm{C}$ and the temperature decreases with distance from the point source. The highest $\left(36.5^{\circ} \mathrm{C}\right)$ and lowest temperature $\left(28^{\circ} \mathrm{C}\right)$ is observed at the point source and the end of the point site $(400 \mathrm{~m})$, respectively. Discharge of heated effluents in Dhalai Beel brought about thermal changes in the water bodies' temperature is basically an important factor as it affects on chemical and biological reaction reduces solvability of gases, changes taste and odor and bring in disruption in metabolic activities 
of aquatic organism $[17,18]$. The temperature found was within the DoE standard $\left(40-45^{\circ} \mathrm{C}\right)$.

\subsection{2. $p H$}

The $\mathrm{pH}$ maintained by a well-buffered river can be attributed to the fact that, normally, running water is influenced by the nature of the deposits over which the water flows [19]. The $\mathrm{pH}$ values found in the five different sampling points ranged from 7.59 to 11.45 . The higher value of $\mathrm{pH}$ was measured in sampling site $\mathrm{S}_{1}$ (11.45), $\mathrm{S}_{2}$ (10.26), $\mathrm{S}_{3}$ (9.15) which was probably due to the different kinds of dye stuff used in dyeing process in different industries (Fig. 2). In textile dyeing industries $\mathrm{H}_{2} \mathrm{O}_{2}$ and $\mathrm{NaOH}$ are used as bleaching and kier agents. Higher $\mathrm{pH}$ approaches in wastewater owing to the wastes composition of textile mills such as $\mathrm{NaOCl}, \mathrm{NaOH}, \mathrm{Na}_{2} \mathrm{SiO}_{3}$, surfactants and sodium phosphate [20]. Excessive $\mathrm{pH}$ is harmful for aquatic microorganisms, fishes, and aquatic plants. Water $\mathrm{pH}$ influences the other properties of water body, activity of organisms and potency of toxic substances present in the aquatic environment [21,22].

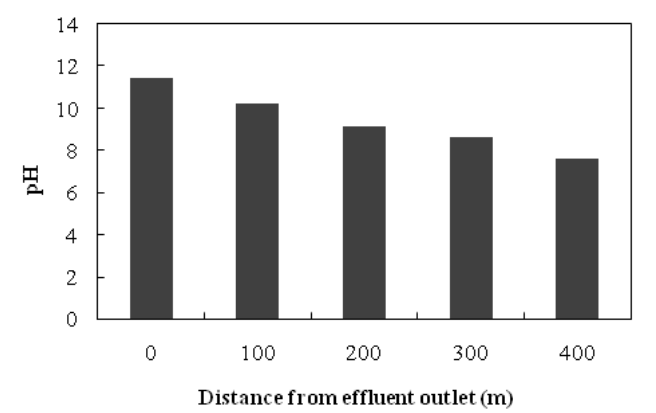

Fig. 2. The $\mathrm{pH}$ values of the samples from different locations of the study area.

\subsubsection{Electric conductivity (EC)}

The electric conductivity (EC) is usually used for indicating the total concentration of the ionized constituents of water. The EC values of the effluent are given in Fig. 3, ranged from 1850 to $3650 \mu \mathrm{s} \mathrm{cm}^{-1}$ which indicates that a large amount of ionic substances was released from the textile industries like sodium, chloride etc. in the studied area. The average concentration of EC in all the sampling points was higher than the DoE permissible level $\left(1200 \mu \mathrm{s} \mathrm{cm}^{-1}\right)$ and is not suitable for aquatic life and irrigation purposes. The average concentration of EC in point source $\left(S_{1}\right)$ was found $3650 \mu \mathrm{s} \mathrm{cm}^{-1}$ which was around 3 times higher than the DoE standard. Elevated levels of EC can have certain physiological effects on food plants and on the habitat that forms plant species. Nevertheless, these values indicate that the Rivers could be receiving wastewater (industrial and sewage effluent) that contains high ionic concentrations which is ultimately harmful for aquatic biodiversity [5]. 


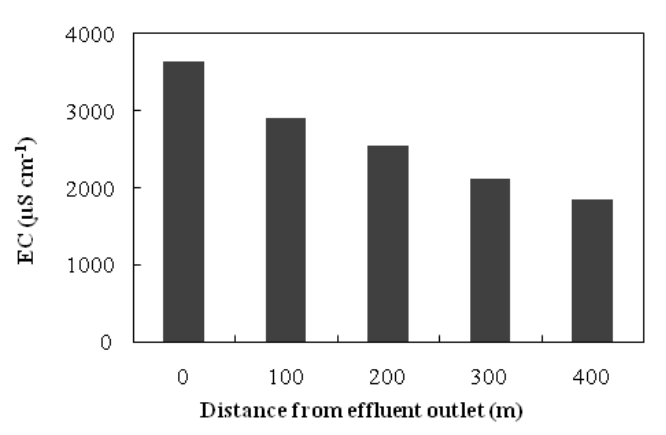

Fig. 3. The EC values of the samples from different locations of the study area.

\subsubsection{Total hardness}

Hardness is seemed to be the capacity of water for reducing and destroying the lather of soap [23]. The hardness values were ranged from 180 to $220 \mathrm{mg} \mathrm{L}^{-1}$ (Fig. 4). Hardness is caused due to divalent cations such as $\mathrm{Ca}^{+2}, \mathrm{Sr}^{+2}$ etc. The highest hardness value was found $220 \mathrm{mg} \mathrm{L}^{-1}$ at the discharge point. And the lowest hardness value was observed 180 $\mathrm{mg} \mathrm{L}^{-1}$ at a distance of $400 \mathrm{~m}$ apart from the discharge point. Higher cations also contribute hardness to a smaller degree. Though hard water has no harmful effects upon the health of consumers [24], the use-of hard water, however, is limited because of excessive soap consumption in home and laundries.

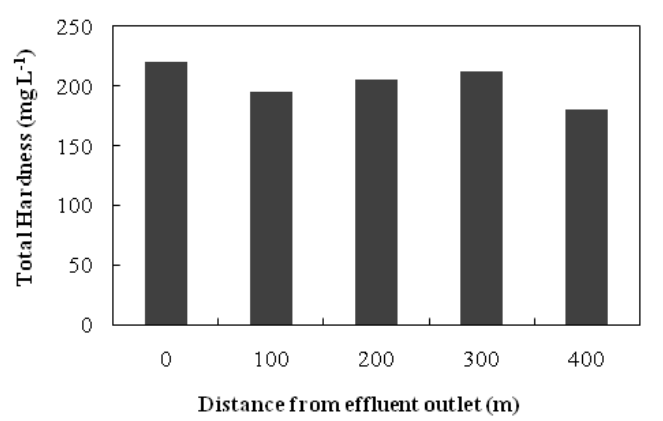

Fig. 4. The total hardness values of the samples from different locations of the study area.

\subsubsection{Total suspended solid (TSS)}

TSS denotes the suspended impurities present in water. The textile and dyeing industries of DEPZ release a lot of solid wastes into Dhalai Beel. TSS values of the study area ranged from 180 to $316 \mathrm{mg} \mathrm{L}^{-1}$ and are given in Fig. 5. The highest value of TSS was observed in point source $\left(316 \mathrm{mg} \mathrm{L}^{-1}\right)$, which was higher than DoE standard $\left(150 \mathrm{mg} \mathrm{L}^{-1}\right)$. TSS values of the study area begin to decline from point source towards the increasing distance. At point $S_{3}$, it was observed a slight increment of TSS probably due to the vertical input of municipal wastewater from the nearby area. Higher TSS Value more than 
effluent quality standard is not desirable because it increases density of water, reduces solubility of gases [25] and curtails usage of water for drinking and industrial purpose. Suspended solids in water may also cause bad odors and taste and also may promote conditions favorable for growth of pathogenic bacteria. High TSS present in water bodies may block the sunlight required to photosynthesis by the bottom vegetation $[18,26]$.

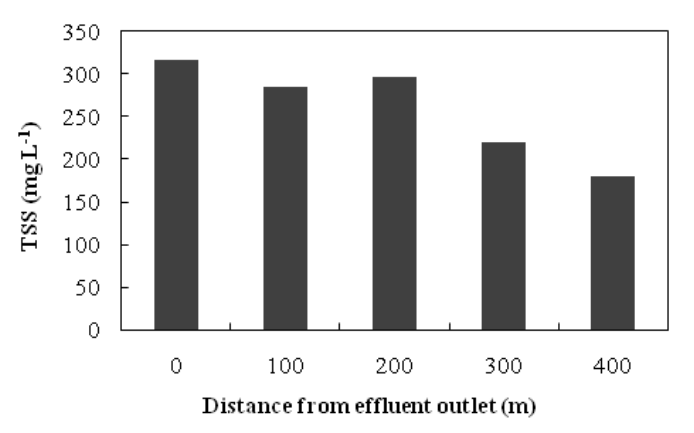

Fig. 5. Total suspended solid values of the samples from different locations of the study area.

\subsubsection{Total dissolved solid (TDS)}

The TDS value is a common indicator of the presence of different minerals and metallic substances in water that are in colloidal and dissolved conditions and also is an important chemical parameter of water [27]. The measured TDS values found in the sampling area (Fig. 6) ranged from 895 to $2559 \mathrm{mg} \mathrm{L}^{-1}$.

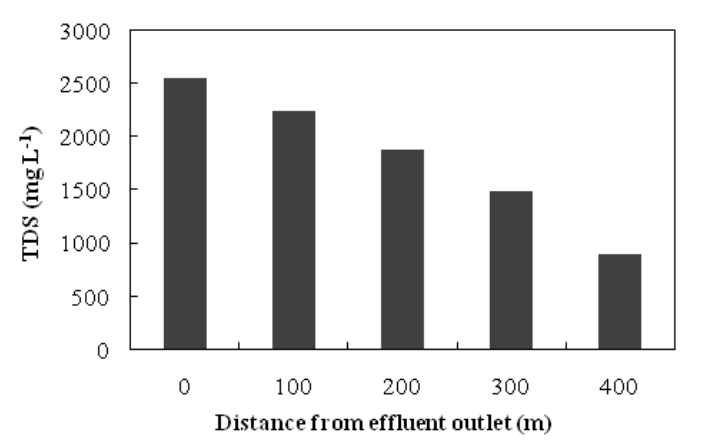

Fig. 6. Total dissolved solid values of the samples from different locations of the study area.

The TDS values obtained from different locations are given in Fig. 6 indicated that the first two sampling points exceeded the DoE standards for TDS value $\left(2100 \mathrm{mg} \mathrm{L}^{-1}\right)$. The elevated concentrations of TDS increase the water density, influences osmoregulation of freshwater organisms and reduce solubility of gases [28]. Increased $\mathrm{pH}$ value of the sample might have resulted in the dissolution of low molecular mass organic bases originating from dye industries. This also gives rise to higher TDS value. 


\subsubsection{Total alkalinity}

The determination of alkalinity provides an idea about the nature of salts present. If the alkalinity is greater than hardness, it indicates the presence of basic salts of sodium and potassium in addition to those of calcium and magnesium. The alkalinity values (Fig. 7) obtained in this study ranged from 137 to $155 \mathrm{mg} \mathrm{L}^{-1}$. The highest alkalinity value was found at the discharge point and the lowest alkalinity value was observed at a distance of $400 \mathrm{~m}$ apart from the discharge point.

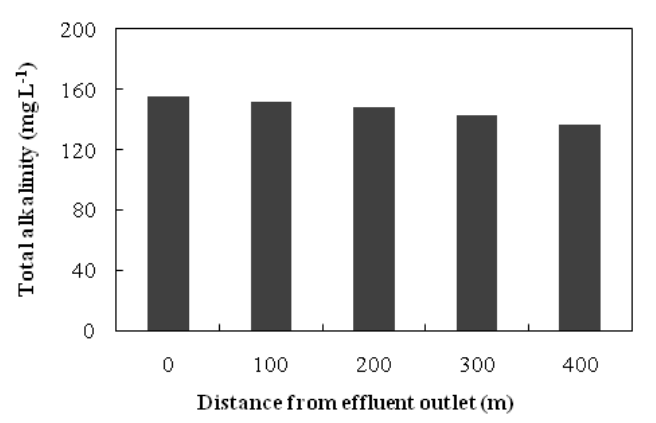

Fig. 7. The total alkalinity values of the samples from different locations of the study area.

\subsubsection{Dissolved oxygen (DO)}

The presence of sufficient DO in water is a positive sign of a healthy body of water but the deficiencies of DO is a signal of severe pollution. A DO value of less than $2 \mathrm{mg} \mathrm{L}^{-1}$ may pose serious threats to an aquatic ecosystem [29]. Deficiency of DO in water gives rise to odoriferous products of anaerobic decomposition [30]. In the present study, the DO (Fig. 8) values for all the sampling stations ranged between 0.89 to $2.3 \mathrm{mg} \mathrm{L}^{-1}$ which were much lower than the recommended value of $\operatorname{DoE}\left(4.5-8 \mathrm{mg} \mathrm{L}^{-1}\right)$, which suggested significant amounts of organic substances were being released into water bodies with high oxygen demand [31]. Lower concentrations of DO values also an indicator of high levels of BOD due to available oxygen consumption by microorganism [32].

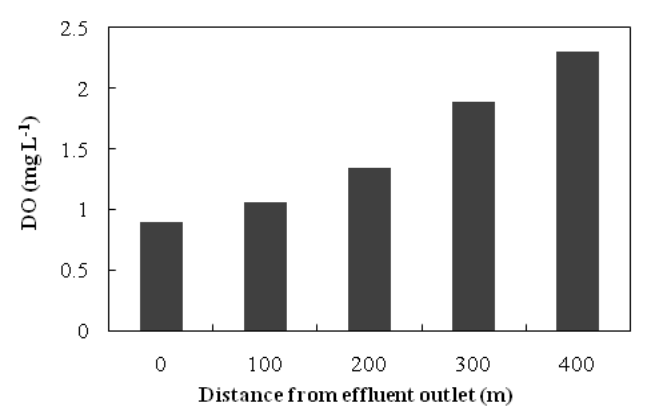

Fig. 8. The DO values of the samples from different locations of the study area. 


\subsubsection{Biochemical oxygen demand (BOD) and chemical oxygen demand (COD)}

BOD is the quantity of oxygen required during the biochemical degradation and transformation of organic matter present in wastewater under aerobic conditions by bacteria and other microorganisms [33]. It is an indicator of the biodegradable organics present in the effluent. The BOD values of the study area varied from 89 to $583 \mathrm{mg} \mathrm{L}^{-1}$ which was much higher than the standard set by $\operatorname{DoE}\left(50 \mathrm{mg} \mathrm{L}^{-1}\right)$ (Fig. 9). The value of BOD in sampling point $S_{1}, S_{2}$, and $S_{3}$ was 583,403 , and $323 \mathrm{mg} \mathrm{L}^{-1}$, respectively which was around 12, 8 and 6.5 times, respectively, higher than that of DoE standard. BOD value in wastewater increases when the quantities of organic wastes remain larger volume as a result of much oxygen consumption by microorganisms to degrade these wastes. As the waste is being dispersed by the water flow, BOD level will begin to decline. From the Fig. 9, it is observed that with increasing the distance from the effluent outlet, BOD values started to decline. High level of BOD values indicated the status of oxygen deficiency in water body which can cause serious damage to aquatic flora and fauna like fish and microorganisms [27].

COD is defined as a measure of the oxygen equivalent of the organic matter content of a sample that is susceptible to oxidation by a strong chemical oxidant. COD is related to BOD; however, BOD only measures the amount of oxygen consumed by microbial oxidation and is most relevant to waters rich in organic matter. In the wastewater, COD and BOD do not necessarily measure the same types of oxygen consumption. For example, COD does not measure the oxygen-consuming potential associated with certain dissolved organic compounds such as acetate [34]. The COD values obtained (Fig. 9) in the present study ranged from 283 to $820 \mathrm{mg} \mathrm{L}^{-1}$ at an average value of $538.6 \mathrm{mg} \mathrm{L}^{-1}$ which is approximately 2.5 times higher than the DoE standards $\left(200 \mathrm{mg} \mathrm{L}^{-1}\right)$. The trends of COD values are similar to BOD values observed. In both the cases the values are showing a decreasing pattern along with the increasing distance from the effluent outlet. This result indicates that biodegradable organic compounds predominate throughout the year.

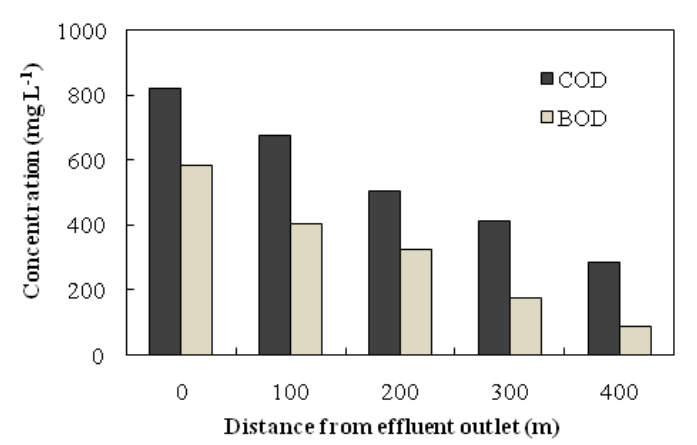

Fig. 9. The BOD and COD values of the samples from different locations of the study area. 


\subsection{Correlation between physicochemical properties}

The water quality of the sampling area revealed a high level of water pollution when compared with the DoE recommended values. The results also showed that the general water quality differed from one sampling point to another. The Pearson's correlation coefficient matrix of these physicochemical parameters is given in Table 4. The coefficient among the physicochemical properties indicated that all the parameters had significant positive or negative contributions to contaminate the water. It was found that almost all parameters have strong negative correlations with the distance from the effluent outlet except DO, where it shows strong positive correlation. DO have very strong negative correlations with all other physicochemical properties. The correlation coefficient between DO and $\mathrm{pH}(\mathrm{r}=-0.95)$ showed that the value of $\mathrm{pH}$ was inversely proportional to the DO. Another study also found similar results for these two parameters [35].

Table 4. Pearson's correlation coefficient for physicochemical parameters.

\begin{tabular}{|c|c|c|c|c|c|c|c|c|c|c|}
\hline Parameters & 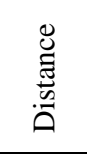 & 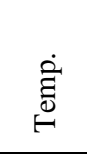 & 竞 & U & 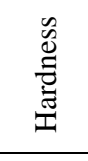 & $\tilde{n}$ & $\tilde{\hat{\imath}}$ & 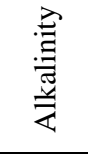 & $\stackrel{\circ}{\circ}$ & రิ \\
\hline Temperature & -0.94 & & & & & & & & & \\
\hline $\mathrm{pH}$ & -0.99 & 0.96 & & & & & & & & \\
\hline EC & -0.98 & 0.98 & 0.99 & & & & & & & \\
\hline Total Hardness & -0.64 & 0.75 & 0.67 & 0.64 & & & & & & \\
\hline TSS & -0.93 & 0.84 & 0.89 & 0.89 & 0.65 & & & & & \\
\hline TDS & -0.99 & 0.91 & 0.98 & 0.95 & 0.69 & 0.95 & & & & \\
\hline Total Alkalinity & -0.99 & 0.90 & 0.97 & 0.95 & 0.65 & 0.96 & 0.99 & & & \\
\hline DO & 0.98 & -0.87 & -0.95 & -0.94 & -0.60 & -0.97 & -0.99 & -0.99 & & \\
\hline BOD & -0.99 & 0.97 & 0.99 & 0.99 & 0.65 & 0.93 & 0.97 & 0.97 & -0.96 & \\
\hline COD & -0.99 & 0.95 & 0.99 & 0.99 & 0.63 & 0.89 & 0.98 & 0.98 & -0.96 & 0.99 \\
\hline
\end{tabular}

Values given in bold are statistically significant at $P \leq 0.05$ level

BOD and COD show significantly negative correlation $(r=-0.96)$ with DO which reveals that with increasing DO value BOD and COD value decreases. The correlation between COD to BOD was always a strong positive. The EC value showed a strong positive correlation with the $\mathrm{pH}$. A strong negative correlation between BOD and COD to DO was found during the study. The COD-to-BOD ratios in all the sampling points were found to be less than 10 which implied a dominance of biodegradable compounds, and, thus, a possible depletion of DO in the water, which was already found. The COD showed a strong positive correlation with BOD for all the water samples which was attributed to the presence of biodegradable waste input from the surrounding catchment area. 


\section{Conclusion}

The composite effluents of various industries of DEPZ are being discharged into Dhalai Beel without any prior treatment which contains toxic and hazardous pollutants degrading the environment. In Bangladesh, DEPZ is one of the important industrial areas with more than $80 \%$ industries without proper management of ETP which results the elevated level of pollutants concentrations. Most of the water quality parameters of the effluent receiving water were found to be exceeded the limit of minimum survival requirements for aquatic life. Correlation matrix shows a significant correlation among the physicochemical properties which indicates a common source of these pollutants. The extent of pollution gradually decreases away from the point source. From this study, it is very clear that surface water around DEPZ is largely contaminated by the effluents discharged from DEPZ. Before discharging to the environment proper management practices, chemical and biological treatments are utmost necessary. Otherwise the very aquatic environment in the adjacent areas will be in dangerously critical within a very short time.

\section{Acknowledgments}

The authors are thankful to the Department of Environmental Sciences, Jahangirnagar University for giving the opportunity to conduct the research work.

\section{References}

1. S. R. Carpenter, N. F. Caraco, D. L. Correll, R. W. Howarth, A. N. Sharpley, and V. H. Smith, Ecol. Appl. 8(3), 559 (1998). http://dx.doi.org/10.1890/1051-0761(1998)008[0559:NPOSWW]2.0.CO;2

2. H. P. Jarvie, B. A. Whitton, and C. Neal, Sci. Total Environ. 210, 79 (1998). http://dx.doi.org/10.1016/S0048-9697(98)00109-0

3. K. Ahmed, M. Das, M. M. Islam, M. S. Akter, S. Islam, and M. A. Al-Mansur, World Appl. Sci. J. 12(2), 152 (2011).

4. M. Akter, T. Sikder and A. A. Ullah, Am. J. Environ. Protec. 3(5), 232 (2014). http://dx.doi.org/10.11648/j.ajep.20140305.14

5. M. S. Islam, M. K. Uddin, S. M. Tareq, M. Shammi, A. K. I. Kamal, T. Sugano, M. Kurasaki, T. Saito, S. Tanaka, and H. Kuramitz, Environments 2(3), 280 (2015). http://dx.doi.org/10.3390/environments2030280

6. S. M. D. Islam and M. E. Huda, J. Sci. Res. 8(2), 191 (2016). http://dx.doi.org/10.3329/jsr.v8i2.26402

7. M. K. Khan, A. M. Alam, M. S. Islam, M.Q. Hassan, and M. A. Al-Mansur, Bangladesh J. Sci. Ind. Res. 46, 153 (2011). http://dx.doi.org/10.3329/bjsir.v46i2.8181

8. D. Khanam, S. H. Rahman, M. S. Islam, M. A. Ahsan, B. Shaha, M. A. Akbor, R. U. Beg, and T. M. Adyel, Jahangirnagar Univ. J. Sci. 34, 21 (2011).

9. G. Ahmed, M. K. Uddin, G. M. Khan, M. S. Rahman, and D. A. Chowdhury, J. Nat. Sci. Sust. Technol. 3, 293 (2009).

10. M. M. Mortula and M. S. Rahman, Bangladesh Environ. 2, 807 (2002).

11. M. A. Mahfuz, J. U. Ahmad, M. S. Sultana, M. M. Rahman, M. A. Goni, and M. S. Rahman, Bangladesh J. Environ. Res. 2, 9 (2004).

12. S. H. Rahman, S. Neelormi, and S. M. Tareq, Jahangirnagar Univ. J. Sci. 31, 19 (2008). 
13. APHA, (American Public Health Association, American Water Works Association, and Water Environment Federation). Standard Methods for the Examination of Water and Wastewater, $20^{\text {th }}$ Edition (American Public Health Association-American Water Works Association, Washington DC, 1998).

14. J. Tolgyfssy, Chemistry and Biology of Water, Air and Soil Environmental Aspects, $2^{\text {nd }}$ Edition (Elsevier Science Publishers, Amsterdam, Netherlands, 1993) pp. 811- 817.

15. DoE (Department of Environment). A Compilation of Environmental Laws of Bangladesh, (2003) pp. 212-214.

16. L. Horrigan, R. S. Lawrence, and P. Walker, Environ. Health Perspec. 110(5), 445 (2002). http://dx.doi.org/10.1289/ehp.02110445

17. A. J. Horne and C. R. Goldman, Limnology, $2^{\text {nd }}$ Edition (McGraw-Hill Inc., New York, 1994).

18. H. S. Peavy, D. R. Rowe, and G. Tchobanoglous, Environmental Engineering (McGraw-Hill Inc., New York, 1985) pp. 417-461.

19. H. B. N. Hynes, The Ecology of Running Waters (Liverpool University Press, Liverpool, UK, 1997) pp. 555.

20. M. S. Sultana, M. S. Islam, R. Saha, and M. A. Mansur, Bangladesh J. Sci. Ind. Res. 44(1), 65 (2009). http://dx.doi.org/10.3329/bjsir.v44i1.2715

21. R. O. Yusuff and J. A. Sonibare, Global Nest: Int. J. 6(3), 212 (2004).

22. R. D. Rouse, Research and Development Series, No. 22, Project: AID/DSAN-G 0039, Auburn University, Alabama, USA. 1979.

23. M. Tiwari, N. K. Shukla, V. Kumar, G. D. Sharma, M. K. Gupta, A. Singh, P. Toppo, and M. K. Tiwari, Int. J. Curr. Microbiol. App. Sci. 4(1), 597 (2015).

24. P. Sengupta. Int. J. Preventive Med. 4(8), 866 (2013).

25. Environmental Protection Agency. Turbidity. In Water: Monitoring \& Assessment (2012). 5.5 Retrieved from http://water.epa.gov/type/rsl/monitoring/vms55.cfm

26. M. L. Davis and D. A. Cornwell, Introduction to Environmental Engineering (WCB/McGrawHill Book Co., Singapore, 1998), pp. 469-535.

27. E. S. Kabir, M. Kabir, S. M. Islam, C. M. Mia, N. Begum, D. A. Chowdhury, S. M. Sultana, and S. M. Rahman, Jahangirnagar Univ. J. Sci. 25, 137 (2002).

28. P. Mathur, S. Agarwal and M. Nag, - Proc. of Taal 2007: The 12th World Lake Conference, 1518, 1529 (2007).

29. EGIS II (Environment and GIS Support Project for Water Sector Planning) Water Quality Approach: Draft Final Report (Ministry of Water Resources, Government of Bangladesh, Dhaka, Bangladesh, 2002).

30. S. B. Bikkad and S. R. Mirgane, Curr. World Environ. 4(1), 175 (2009).

31. V. Emongor, E. Kealotswe, I. Koorapetse, S. Sarihvasa and S. Keikanetswe, J. Appl. Sci. 5, 147 (2005). http://dx.doi.org/10.3923/jas.2005.147.150

32. C. N. Sawyer, P. L. McCarty, and G. F. Parkin, Chemistry for Environmental Engineering and Science, $5^{\text {th }}$ Edition (McGraw-Hill: New York, NY, USA, 2003).

33. S. S. Dara, A Textbook of Environmental Chemistry and Pollution Control (S. Chand and Company Limited, New Delhi, India. 2002) pp. 24-30.

34. Chemical Oxygen Demand -Cod, Assay, Waters, and Measured-J Rank Articles. http://science.jrank.org/pages/1388/Chemical-Oxygen-Demand.html\#ixzz40nq09PFg (Last accessed 21 February, 2016)

35. H. Momtaz, F. Alam, M. A. Ahsan, M. A. Akbor, and M. M. Rashid, Bangladesh J. Sci. Ind. Res. 47(3), 279 (2012). http://dx.doi.org/10.3329/bjsir.v47i3.13061 